\title{
Resenhas
}

\section{LiTERATURA, LeITURA E APRENDIZAGEM DA ESCRITA}

\section{Olness, $R$. (2005). Using literature to encharge writing instruction: A guide for K5 teachers. Newark: IRA, xii $+204 p$.}

A literatura é uma das dimensões culturais que mais oferece condições para o desenvolvimento do ser e que, por esta razão, pode ser instrumento e meio de ensino de muitas áreas do conhecimento além dela própria. Vale lembrar seu uso no ensino da leitura, da escrita, da história, da filosofia, da geografia, da matemática. $\mathrm{Na}$ obra aqui resenhada é enfocado seu uso no desenvolvimento da competência na escrita por escolares.

Rebecca Olness é uma professora aposentada, especialista na área, com mais de 30 anos de experiência e que oferece aos leitores, embora enfoque principalmente os alunos do $5^{\text {a }}$ série do ensino fundamental, por vezes, considera também séries precedentes e posteriores. Além disso, muitos dos procedimentos e técnicas podem ser úteis no nível médio e mesmo adaptadas para o nível superior. Assim sendo, o livro tem o potencial de poder ser útil a muitos docentes.

A obra compreende prefácio, escrito pela própria autora, 10 capítulos, referências e índice de autores e conteúdo. As referências são predominantemente recentes, incluindo literatura cinza e artigos de periódicos. Em cada capítulo, em relação específica, são apresentadas muitas obras literárias citadas ao longo do trabalho. $\mathrm{O}$ texto segue basicamente o modelo de escrita denominado Modelo dos Seis Traços Analíticos da Escrita, de Spandel e Stiggs, infelizmente pouco conhecido Brasil. Os seis traços ou elementos são: 1) idéias, 2) organização, 3) voz, 4) escolha da palavra, 5) fluência oracional (sentença) e 6)convenções. Cada elemento é avaliado, analisado e trabalhado independentemente de modo a se produzir uma boa escrita. A meta da autora é auxiliar o professor como ensinar seus alunos a reconhecerem estes traços em bons textos, em obras literárias, para que possam incluílos em sua própria escrita. O livro tem potencial para que o professor possa realmente transformar sua prática.
É rico em exemplos e sugestões, bem sustentados em pesquisa e inspira muitas outras investigações.

O primeiro capítulo é uma rápida revisão da relação leitura-escrita em que lembra os autores como mentores ou modelos, a preocupação com a audiência, o gênero dos autores, a questão do vocabulário, do estilo e da ilustração. Parte do pressuposto que um bom leitor eventualmente é também um escritor.

No capítulo seguinte começa por lembrar que tanto crianças como adultos aprenderam melhor em um ambiente que os apoie, em uma situação positivamente reforçadora. Passa a considerar os gêneros literários e suas possibilidades de uso no ensino da escrita desde os livros de figura até textos mais complexos. Indica rapidamente as possibilidades as quais são retomadas e aprofundadas nos capítulos següintes.

"Escrever é mais do que viver...... é estar consciente do viver" (p.35) é com esta formulação de Lindbergh que a autora começa o capitulo 3 no qual enfoca a relação experiência-escrita, tendo por base: o tópico (escolher e aprofundar), fornecimento de pistas, introdução de regras ou parâmetros e aprender a escrever com os outros. Muitos escrevem sobre o que sabem, suas experiências, memórias, observações e registros. Os alunos podem aprender a fazer o mesmo como básico para o desenvolvimento de sua escrita.

É a partir do $4^{\circ}$ capitulo que a Autora começa a melhor especificar cada elemento do modelo. Nesse capítulo trata do encontrar boas idéias e detalhes. As idéias são a própria razão do escrever do autor, o que transmitir. É preciso relacionar as características, enfocar a quantidade dos detalhes ir além do óbvio. É comum começar com um tema muito amplo, é preciso afunilálo, restringí-lo e escolher os detalhes mais importantes pode ser muito útil. Mas há a contrapartida - escolher sobre o que não falar. A seguir trata de como usar livros como exemplo de idéias, verificando como os autores 
trabalham. Uma lista de checagem para o aluno pode ser de grande valia (Meu tema está suficientemente restrito?, Falei o suficiente sobre o assunto? Apresentei os detalhes importantes? Demonstrei mais do que falei? Minha mensagem está clara?) Para auxiliar o professor, apresenta alguns planos de aula, como o fazer relação aos elementos enfocados no capítulos posteriores.

O traço seguinte é a elaboração do esquema ou primeira redação, o que requer técnicas específicas. Apresenta rapidamente poucas técnicas das muitas presentes na produção científica. Vale lembrar que desde o inicio deve-se organizar a produção do começo ao fim.

No capítulo 6 trata de expressão dos sentimento por meio das vozes dos personagens dos textos literários. Trata também do tipo de discurso que pretende persuadir o outro, indicando tecnologias auxiliares para êxito nesta tarefa.

A escolha da palavra correta é essencial na escrita, aprender a fazer esta seleção amplia o vocabulário e permite ganhos em precisão no uso das várias categorias gramaticais. Aprender a usar tesouras, enciclopédias dicionários e glossários é fundamental. Paralelamente é preciso desencorajar o uso de jargões e frases feitas. Novamente há o cuidado da autora de ensinar ao professor o uso de algumas tecnologias. No presente caso optou pelo Procedimento ou técnica de Cloze. Neste, como em todos os capítulos, o uso de livros como exemplo de escolha e uso de palavras é parte importante do processo de ensino-aprendizagem.

Dominar a fluência e o ritmo (especialmente no texto literário) é fundamental na escrita (capítulo 8). A análise de obras literárias pode ser muito útil para o domínio de começar uma sentença, da extensão da mesma, da combinação de sentenças, do uso de elementos gramaticais no estabelecimento da coesão. Vale lembrar a importância da revisão.

A apresentação de qualquer escrita segue convenções (capitulo 9) específicas para cada tipo de texto. A partir de textos literários, usando tecnologias especiais de ensino, são trabalhadas: a soletração, a pontuação, as maiúsculas, as habilidades de editoração; $\mathrm{o}$ acesso às convenções e o respeito às mesmas.

No último capitulo, a autora acrescenta algumas considerações finais sobre o aprender a escrever tendo a literatura como referencial. Lembra que precisam ler muito não só literatura mas também sobre como escrever e como fazê-lo efetivamente. Os professores também precisam ser escritores, serem modelo para seus alunos. Lembra ainda que escrever requer tempo e que é preciso que seja previsto pelo mesmo de 25 a 40 minutos diários para escrita, desde a primeira série. Espera-se que $33 \%$ do tempo passado em sala de aula seja dedicado à aprendizagem da escrita e ela deve ser transversal a todo o currículo. O professor também precisa cuidar de desenvolver suas habilidades pessoais escritas (15 a 20 minutos de treino diariamente pelo menos).

Vale concluir esta resenha com o último parágrafo do livro:

Assim, leia para seus estudantes. Envolva-os em todas as formas de escrita, gênero e literatura. Partilhe com ele seus textos e livros favoritos. Demonstre o processo de escrita, indique e discuta com eles os traços da escrita. Seja criativo e encontre meios para oferece tempo contínuo para escrita em sua sala de aula. $\mathrm{E}$, acima de tudo, divirta-se. Seu entusiasmo e amor pela literatura e leitura será contagioso. (p. 188)

Geraldina Porto Witter UMC/ PUC-Campinas 